\section{EFFECTS OF A 20-WEEK PILATES METHOD PROGRAM ON BODY COMPOSITION}

\author{
EFEITOS DE UM PROGRAMA DE 20 SEMANAS DE MÉTODO PILATES SOBRE A COMPOSIÇÃO CORPORAL
} EFECTOS DE UN PROGRAMA DE 20 SEMANAS DE MÉTODO PILATES SOBRE LA COMPOSICIÓN CORPORAL

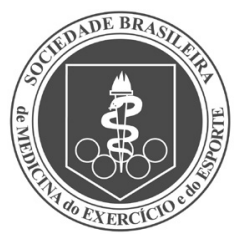

Original Article Artigo OrIGINAL Artículo Original

\author{
Teresa Garcia-Pastor Correio' (iD \\ (Physical Education Professional) \\ Pilar Sainz de Baranda Correio ${ }^{2}$ (D) \\ (Physical Education Professional) \\ Susana Aznar Correio ${ }^{3}$ (DD \\ (Physical Education Professional) \\ 1. Universidad Camilo José Cela, \\ Madrid, Spain. \\ 2. Universidad de Murcia, Murcia, \\ Spain. \\ 3. Universidad de Castilla-La \\ Mancha, Toledo, Spain.
}

\section{Correspondence:}

Teresa Garcia-Pastor Correio. Calle Castillo de Alarcón, 49, Villafranca del Castillo, Madrid, España. 28692. tgarcia@ucjc.edu

\begin{abstract}
Objective: The objective of this study was to evaluate whether there were changes in body composition after a 20-week (twice weekly) Pilates Method (PM) program when compared to a control group. Methods: This was a controlled quasi-experimental study in which 41 subjects (83.3\% females, 16.7\% males) aged between 28 and 58 years (mean age $=42.37 \pm 7.86$ years) were divided into two groups (intervention or control group) and later evaluated. Body composition was measured with anthropometric techniques utilizing the following variables: weight, height, and 6 skinfold measurements. The PM intervention consisted of two weekly sessions, over a 20-week period. The minimal attendance for the program was $85 \%$. Results: Significant differences were observed between the two groups for the sum of six skinfold measurements $(p=0.01)$ and body fat percentage $(p=0.004)$. Conclusion: Practicing the PM for 20 weeks seems to be an activity that can positively influence changes in body composition. Level of evidence III, non-randomized controlled cohort study.
\end{abstract}

Keywords: Anthropometry; Subcutaneous fat; Exercise; Exercise movement techniques.

\section{RESUMO}

Objetivo: Oobjetivo deste estudo foi avaliar se houve mudanças na composição corporal depois de 20 semanas (duas vezes por semana) com o programa de Método Pilates (MP), em comparação com um grupo controle. Métodos: Trata-se de umestudo quasi-experimental controlado, no qual 41 indivíduos (83,3\% mulheres, 16,7\% homens), com idade entre 28 e 58 anos (média = 42,37 $\pm 7,86$ anos). Os participantes foram divididos em dois grupos (grupo intervenção e controle) e posteriormente avaliados. A composição corporal foi medida por técnicas antropométricas, usando as seguintes variáveis: peso, altura e 6 dobras cutâneas. A intervenção com o MP consistiu em duas sessões semanais, durante um período de 20 semanas. O comparecimento mínimo para o programa foide $85 \%$. Resultados: Foram observadas diferenças significativas entre os dois grupos quanto à somatória das medidas de seis dobras cutâneas $(p=0,01)$ e percentual de gordura corporal $(p=0,004)$. Conclusão: A prática do MP durante 20 semanas parece ser uma atividade que pode influenciar positivamente as mudanças na composição corporal. Nível de evidência III, estudo de coorte controlado não randomizado.

\section{Descritores: Antropometria; Gordura subcutânea; Exercício; Técnicas de exercício e de movimento.}

\section{RESUMEN}

Objetivo: El objetivo de este estudio fue evaluar si hubo cambios en la composición corporal después de 20 semanas (dos veces por semana) con el programa de Método Pilates (MP), en comparación con un grupo control. Métodos: Se trata de un estudio cuasi experimental controlado, en el que 41 individuos (83,3\% mujeres, 16,7\% hombres), con edad entre 28 y 58 años (promedio $=42,37 \pm 7,86$ años). Los participantes fueron divididos en dos grupos (grupo intervención y control) y posteriormenteevaluados. La composición corporal fue medida por técnicas antropométricas, usando las siguientes variables: peso, altura y 6 pliegues cutáneos. La intervención con el MP consistió en dos sesiones semanales, durante un período de 20 semanas. La asistencia mínima para el programa fue de $85 \%$. Resultados: Fueron observadas diferencias significativas entre los dos grupos cuanto a la sumatoria de las medidas de seis pliegues cutáneos $(p=0,01)$ y porcentual de grasa corporal $(p=0,004)$. Conclusión: La práctica del MP durante 20 semanas parece ser una actividad que puede influenciar positivamente los cambios en la composición corporal. Nivel de evidencia III, estudio de cohorte controlado no aleatorio.

Descriptores: Antropometría; Grasa subcutánea; Ejercicio; Técnicas de ejercicio con movimientos.

\section{INTRODUCTION}

The Pilates Method is an old exercise system (existing for more than 90 years) whose founder, Joseph Pilates, combined movements based on traditional and Swedish gymnastics, rehabilitation techniques, martial arts, yoga, and dance. ${ }^{1}$ Pilates is a training method with a symmetric strengthening of the muscles of the abdominal wall and spine, muscle action is performed at low speeds with a high isometric component. ${ }^{2}$
Despite the fact that the practice of this method is high, as is the number of informative publications, there is a paucity of scientific foundation regarding its benefits. ${ }^{3}$ The first publications that can be found in MEDLINE with the key word "Pilates" are dated 1999, but they are only analytical studies. Until 2004, an intervention study was not published about the PM, but that year Segal, Hein and Basford $(2004)^{4}$ published one. Currently, there are more than 100 references, we can highlight studies 
about the effects of PM on low back pain, ${ }^{5}$ muscle activity analysis, ${ }^{6}$ flexibility ${ }^{7}$ or benefits for elderly people ${ }^{8}$ but the scientific quality of the research needs to be improved. ${ }^{9}$ Therefore, there is a need for knowledge about the scientific foundation of this method by those who practice this exercise, instructors, personal trainers, physicians, and those who work in rehabilitation.

Body fat percentage is considered a cardiovascular risk factor and an indicator of good health. ${ }^{10}$ Currently, overweight and obesity are some of the most significant health problems and they affect more than 50\% of the Spanish population: $37.8 \%$ suffer overweight and $15.56 \%$ suffer obesity. ${ }^{11}$ We know that regular physical activity can be a factor that assists in maintaining adequate body composition ${ }^{12}$ and we question whether the PM could be an adequate activity for this. The PM is popularly known as an exercise technique that helps to trim your figure. A direct disciple of Joseph Pilates affirmed that with the practice of the PM: "On the outside, you'll note a radical change in your body, you'll decrease the size of your hips and buttocks, and you'll be much more conscious of your powerhouse "13 However, there do not seem to be energy expenditure charts that list the PM.

Based on a review published elsewhere, ${ }^{14}$ we considered only four scientific studies in which changes in body composition are evaluated after the practice of the PM4,15-17. Rogers and Gibson ${ }^{15}$ found a significant decrease in the sum of three skinfolds $(p<0.005)$ and in the perimeters of the waist, chest, and arms ( $p<0.05)$. The intervention of that study consisted of three weekly sessions of 60 minutes each for eight weeks. In the other three studies, there were no significant differences in anthropometric data after practicing the PM in comparison to a control group. One of them measured the BMI and the waist perimeter in girls ${ }^{17}$ while the other two evaluated the body composition in the adult population with either skinfold ${ }^{16}$ or bioimpedence measurement techniques. ${ }^{4}$

We can also highlight a recent study that verifies the effects of PM on lipid metabolism and inflammatory cytokines mRNA expression. ${ }^{18}$ The results showed significant increases in blood HDL-C concentration despite an increase in the body fat ratio, after the 8-week Pilates intervention. These results imply that PM seems to be effective in increasing blood lipid metabolism, however, the study failed to verify the exercise positive effect in TC, TG and LDL-C concentration.

The duration and frequency of the interventions in the aforementioned studies were between four and five weeks and six months, although the weekly frequency of the longest intervention was just one session.

Therefore, the objective of this study was to evaluate whether there were changes in the body composition of the adult population after a 20-week program of the PM with two weekly sessions.

\section{METHODS}

The current study had a quasi-experimental multi-group design, with an experimental group and a control group, and it utilized intra-group and inter-group measurement analyses for each of the selected variables in the study.

An intentional convenience sampling of members of a gym was used for the experimental group. Forty-nine subjects were invited to participate in this study. Experimental mortality was $18.37 \%$ (8 subjects). The final sample was composed of 41 subjects ( $83.3 \%$ females, $n=35$; $16.7 \%$ males, $n=7$ ) between the ages of 28 and 58 years (mean age $=$ $42.37 \pm 7.86$ years) who were residents of Boadilla del Monte, Madrid, Spain.

The sample was divided into two groups: the Pilates method group (PMg) or experimental group that began to practice the PM twice weekly $(n=19)$, with ages between 36 and 58 years (mean age $=44.21 \pm 6.1$ years); and the control group ${ }^{19}$ that did not practice any physical activity $(n=22)$, with ages between 28 and 56 years (mean age $=40.77 \pm 8.95$ years). The control group was composed of subjects from the same town who worked at the Virgen de Europa school in Boadilla del Monte and who did not practice any physical activity.

None of the participants suffered serious health problems or musculoskeletal problems which interfered in their daily activities and/ or the practice of physical activities. These data were obtained from a medical report turned in beforehand as well as the PAR-Q questionnaire (Canadian Society for Exercise and Physiology, 2010).

All participants collaborated voluntarily and signed an informed consent form for the pre- and post-test data gathering, and they agreed to let their data be used in this research study. The study was approved by the Research Ethics Committee at the University of Castilla-La Mancha.

The experimental phase was executed in the Sports Services section of the Boadilla del Monte (Madrid) courthouse, and the training of the PM was done with people that had not previously practiced the PM. The intervention lasted 20 weeks (from January to June) with a weekly frequency of two days (Tuesday and Thursday). Sessions lasted 60 minutes. A total of 38 Pilates sessions were provided. Classes were given in small groups of 15 people, and they were always lead by the same instructor.

A Pilates instructor who was a B.Sc. in Physical Activity and Sport Sciences, Stott and Polestar Pilates certified, who had much experience in teaching floor PM developed the program. The PM uses a highly sequenced routine and a small number of exercises that include modifications, to provide simple enough exercises for a beginner to be able to master in a relatively short period. The nature of PM also dictates that the method of instruction be very consistent: cuing, sequence, and number of repetitions are all predetermined. Therefore, the same sequence of exercises and approximately the same number of repetitions of each exercise were performed during each class period. As the study progressed, and participants mastered the individual exercise (i.e. with no modifications), and they were able to properly performed additional exercises within the same period. Therefore, the sequence of the exercise program was progressive in quantity and quality.

An initial measurement was taken of all the subjects, and a second measurement was taken 20 weeks later. The measurements were taken with subjects barefoot and in their underwear. All measurements were taken at the same time of day (between 10:00 AM and 1:00 PM), during the same evaluation session, and with the same room temperature (250 C). Data was collected following a blind method, the researcher did not know the participant group (PMg or Cg).

Subjects did not do any activation or stretching exercises before or during the measurements, and all measurements were taken by the same researcher with extensive experience in these techniques. Before data collection, with the goal of establishing the researcher reliability, an intra-class correlation coefficient with 10 subjects was carried out, obtaining a value greater than 0.90 for all measurements.

The instruments that were utilized for the anthropometric evaluation in this study were: Seca 762 scale with a graduation of $100 \mathrm{~g}$ (variable that was measured: weight in $\mathrm{Kg}$ ); stadiometer with a precision of 1 $\mathrm{mm}$ and a range from few centimeters to two meters (variable that was measured: height in $\mathrm{mm}$ ); Holtain skinfold caliper (Holtain Ltd., (rosswell, UK), where the pressure between anvils was constant at 10 $\mathrm{g} / \mathrm{mm}^{2}$; and metric tape.

During both measurements (pre and post), we used well-defined protocols and calibrated equipment in a standardised environment to minimise measurement errors. The anthropometric evaluation was carried out in a private room, and subjects had a previously determined appointment time lasting 15 minutes. The recommendations of the ACSM for an anthropometric exam were followed. ${ }^{20,21}$ 
The measurements that were taken and the order that the data were taken in were the following: weight, height, skinfolds (triceps, subscapular, suprailiac, abdominal, anterior thigh, and medial calf), and waist and hip circumferences. Height was measured while subjects were standing barefoot with their heels, gluteus muscles, and back in contact with the wall. Weight was measured while subjects were barefoot and wearing only underwear. Skinfold thickness was measured in triplicate to the nearest $\mathrm{mm}$. The right side was measured whether or not it was the dominant side. Before beginning, the anatomical points that served as reference points were marked with a water-soluble marker. From these measurements, the following calculations were employed to obtain the results: body fat percentage (Faulkner equation utilizing four skinfold measurements), sum of six skinfolds and body mass index (ratio of body weight $(\mathrm{Kg}) /$ height $\left.(\mathrm{m})^{2}\right)$.

For this study, the SPSS for Windows (version 16.0) statistical package was used. To verify the normality of the anthropometric measurements, the Kolgomorov-Smirnov test was used. Means and standard deviations for all dependent variables were calculated for both groups (experimental and control) in each evaluation session (pre and post tests) $(k=2)$. The mean differences between pre-test and post-test and 95\% confidence intervals scores for the dependent variables were also measured in each of the groups.

Two-way analysis of covariance (2x2), Group (Pilates method vs control group) and measurement moment (pre-test vs post-test) with repeated measures in the last factor (MANCOVA) was used to assess significant changes in dependent variables for each of the groups. The baseline measurement was used as covariate. When significant intergroup differences were noted, post-hoc Bonferroni test were carried out. The level of statistical significance for the study was established at $p<.05$.

A post-hoc power analysis was conducted using the software package, G*Power 3.1.2. ${ }^{22,23}$ A sample size of 54 subjects was used for the statistical power analyses (ANCOVA). The alpha level used for this analysis was $p<0.05$. The post-hoc analyses revealed that the statistical power for this study was 0.93 . It could be concluded that the given sample size was large enough to detect significant effects. ${ }^{24}$

\section{RESULTS}

The mean, standard deviations and 95\% confidence intervals values for anthropometric measurements for each group and measurement moments are reported in Table 1.

The results show no significant differences found in the BMI, nor in the waist and hip circumferences between the two groups. The inter- group analysis showed significant differences ( $p>0.05$ ) for each of the variables in each of the measurement moments. The intra-group analysis, in particular the control group, did not show significant differences between the pre-test and post-test for each of the variables measured. On the other hand, the PM group revealed a significant descend in the variables measured: $\Sigma$ skinfolds ( $p=0.02)$ and $\%$ body fat $(p=0.001)$, after the exercise intervention.

\section{DISCUSSION}

The anthropometric results from the present study did not demonstrate significant changes in the BMI, but they did show a significant reduction in the sum of six skinfolds and in the percentage of body fat after a 20-week PM intervention in an adult population when compared to a control group.

Once the results were analyzed and compared to the bibliography, we can highlight the following observations. The results about the changes in body fat and the sum of six skinfolds are similar to those by Rogers and Gibson, ${ }^{15}$ with the difference that they found significant changes in the waist circumference while we did not. The intervention duration from that study was lower, but on the other hand the frequency of sessions was higher. The rest of the studies that were reviewed did not find significant differences in the body fat percentage. $4,16,17$ Only Jago et al. ${ }^{17}$ found significant differences in the BMI percentile, with the difference that they evaluated 11-year-old girls while the present study evaluated healthy adults. Sekendiz et al. ${ }^{16}$ justified the lack of change in body composition by the short duration of the study (five weeks). In the case of Segal et al., ${ }^{4}$ the practice was only once weekly; further, bioimpedance, in spite of being a quick method for measuring body fat percentage, has questionable validity if there is not an exhaustive monitoring of normal levels of hydration.

Jago et al., ${ }^{17}$ after four weeks of intervention, did not find significant differences in the mean values for weight, waist circumference, and overall BMI. However, they believe that the change in the percentile of the BMI adjusted for age and sex should be evaluated as very positive. Further, the authors were able to verify that this weight reduction was encountered both in the girls that suffered obesity as well as those who were healthy to begin with. For this reason, the authors postulate that the overweight girls could potentially benefit from a longer program of the Pilates method.

Moreover, Jago et al. ${ }^{17}$ found that the practice of Pilates was evaluated as an activity with an intensity of 5.9 on a subjective scale from one to ten by a group of adolescents in the study. Therefore, the intensity of this practice was considered insufficient to provide a caloric output that would be sufficient for modifying the BMI. The study proposed future interventions that combined the practice of the PM with an aerobic activity to increase caloric output.

From the results of the present study, we can confirm that a change in body composition is possible with the exclusive practice of the PM, although the BMI did not change in a sample of healthy adults.

Low levels in body fat ratio positively affects lipid metabolism, ${ }^{25}$ as reported in previous studies, PM reduced body fat ratio and positively affected lipid metabolism. PM was effective in a decreased if TC levels in middle-aged obese women ${ }^{26}$ and a reduction in TC, TG and LDL-C concentration, after a 24 week PM program for senior women. ${ }^{27} \mathrm{Nev}$ ertheless, the results of these studies must be regarded with caution due to the small sample size and poor control of dietary and nutritional

Table 1. Results of Two-way analysis of covariance (2x2), Group (Pilates method vs control group) and measurement moment (pre-test vs post-test) (mean and $95 \%$ confidence intervals).

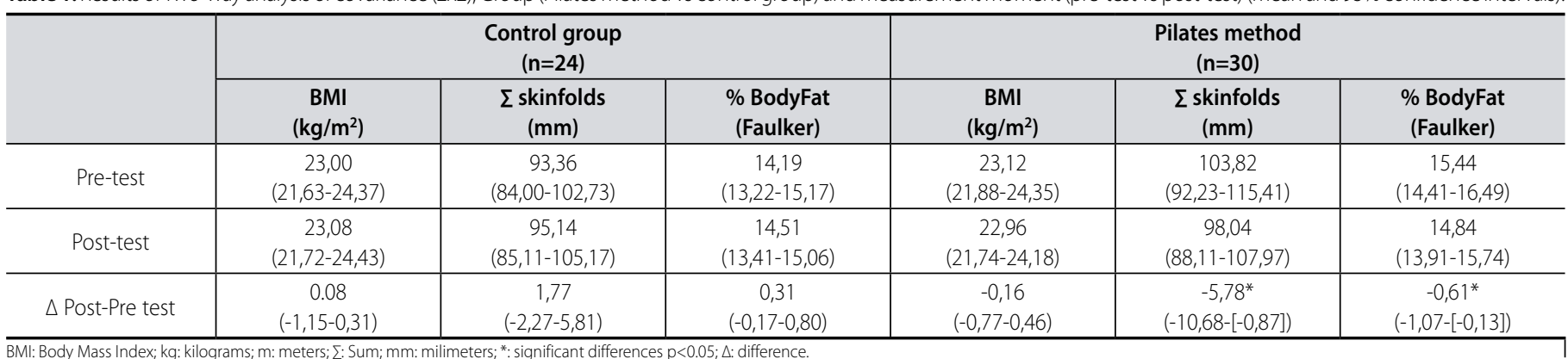


habits. Therefore, we believe future studies need to analyze the effects of the practice of the PM while monitoring changes in diet or other habits. This way, we could verify whether the positive evolution of body composition is due to the practice of the PM and whether the participation in a program of this technique could influence a healthier life and/or an increase in daily physical activity with improved well-being, as demonstrated elsewhere. ${ }^{28} \mathrm{It}$ could also be determined whether it helps in the creation of healthy habits as observed by Daley et al.., ${ }^{29}$ and therefore contribute to the prevention of illnesses related to lifestyle and adequate levels of obesity.

\section{CONCLUSION}

The practice of the PM for 20 weeks with two weekly sessions can positively influence body composition in a sample of healthy adults.

\section{ACKNOWLEDGMENTS}

We would like to thank all participants of the study and Boadilla del Monte sports centre in Madrid, Spain.

All authors declare no potential conflict of interest related to this article

AUTHORS' CONTRIBUTIONS: This manuscript, which is a multi-institutional study, has three authors. Each author made significant individual contributions to this manuscript. TGP: design of the project, data acquisition and analysis, and drafting of the manuscript. PSB: preparation of the project, statistical analysis, drafting and revision of the manuscript SAL: preparation of the project, statistical analysis and revision of the manuscript.

\section{REFERENCES}

1. Levine B, Kaplanek B, Jaffe WL. Pilates training for use in rehabilitation after total hip and knee arthroplasty: a preliminary report. Clin Orthop Relat Res. 2009;467(6):1468-75.

2. Dorado C, Calbet JA, Lopez-Gordillo A, Alayon S, Sanchis-Moysi J. Marked effects of pilates on the abdominal muscles: a longitudinal magnetic resonance imaging study. Med Sci Sports Exerc. 2012;44(8):1589-94.

3. Bernardo LM. The effectivness of Pilates training in healthy adults: An appraisal of the research literature. J Body Mov Ther. 2007;1 1(2):106-10

4. Segal NA, Hein J, Basford JR. The effects of Pilates training on flexibility and body composition: an observational study. Arch Phys Med Rehabil. 2004;85(12):1977-81.

5. Wajswelner H, Metcalf B, Bennell K. Clinical Pilates versus General Exercise for Chronic Low Back Pain: Randomized Trial. Med Sci Sports Exerc. 2012;44(7):1197-205.

6. Rossi DM, Morcelli MH, Marques NR, Hallal CZ, Goncalves M, Laroche DP, et al. Antagonist coactivation of trunk stabilizer muscles during Pilates exercises. J Bodyw Mov Ther. 2014;18(1):34-41.

7. González-Gálvez M, Poyatos MC, Pardo PM, Vale RGS, Feito Y. Effects of a pilates school program on hamstrings flexibility of adolescents. Rev Bras Med Esporte. 2015;21(4):302-7.

8. Rutjes AW, Di Nisio M. 24 weeks of Pilates-aerobic and educative training to improve body fat mass in elderly Serbian women. Clin linterv Aging. 2014;9:741.

9. Wells C, Kolt GS, Marshall P, Hill B, Bialocerkowski A. The effectiveness of pilates exercise in people with chronic low back pain: a systematic review. PloS one. 2014;9(7):e100402.

10. Organization"WH. World Health Organization. Reducing risks, promoting healthy life. . Geneva: World Health Organization; 2002. Available from: http://www.who.int/whr/2002/en/. Accessed in??

11. Salcedo V, Gutiérrez-Fisac JL, Guallar-Castillón P, Rodríguez-Artalejo F. Tendencias en el sobrepeso y el sobrepeso malinterpretado en España desde 1987 hasta 2007. Int J Obes (Lond). 2010;34(12):1759-65.

12. Wallace J. Obesity. In: Durstine J, Moore G, editors. ACSM's Exercise Management for Persons with Chronic Diseases and Disabilities. Champaign, IL: Human Kinetics; 2003.

13. Winsor M. Pilates: El centro de energía. Barcelona: Editorial Paidotribo; 2002.

14. Aladro-Gonzalvo AR, Machado-Diaz M, Moncada-Jimenez J, Hernandez-Elizondo J, Araya-Vargas G. The effect of Pilates exercises on body composition: a systematic review. J Bodyw Mov Ther. 2012;16(1):109-14.

15. Rogers K, Gibson AL. Eight-week traditional mat Pilates training-program effects on adult fitness characteristics. Res Q Exerc Sport. 2009;80(3):569-74.
16. Sekendiz B, Altun O, Korkusuz F, Akin S. Effects of Pilates exercise on trunk strength, endurance and flexibility in sedentary adult females. J Body Mov Ther. 2007;11(4):318-26.

17. Jago R, Jonker ML, Missaghian M, Baranowski T. Effect of 4 weeks of Pilates on the body composition of young girls. Prev Med. 2006;42(3):177-80

18. Kim HJ, Kim J, Kim CS. The effects of pilates exercise on lipid metabolism and inflammatory cytokines mRNA expression in female undergraduates. J Exerc Nutrition Biochem. 2014;18(3):267-75.

19. McGrath JA, O'Malley M, Hendrix TJ. Group exercise mode and health-related quality of life among healthy adults. J Adv Nurs. 2011;67(3):491-500

20. Medicine ACOS. ACSM's clinical certification review : ACSM exercise specialist : ACSM program director / American College of Sport Medicine Philadelphia Lippincott Williams \& Wilkins; 2001.

21. Whaley MH. ACSM's Guidelines for Exercise Testing and Presciption. Philadelphia: Lippincott Williams and Wilkins; 2006

22. Faul F, Erdfelder E, Buchner A, Lang AG. Statistical power analyses using G*Power 3.1: Tests for correlation and regression analyses. Behav Res Methods. 2009;41(4):1149-60.

23. Faul F, Erdfelder E, Lang AG, Buchner A. G*Power 3: A flexible statistical power analysis program for the social, behavioral, and biomedical sciences. Behav Res Methods. 2007;39(2):175-91.

24. Atkinson G, Nevill AM. Selected issues in the design and analysis of sport performance research. Sports Sci. 2001;19(10):811-27

25. Ward KD, Sparrow D, Vokonas PS, Willett WC, Landsberg L, Weiss ST. The relationships of abdominal obesity, hyperinsulinemia and saturated fat intake to serum lipid levels: the Normative Aging Study. Int J Obes Relat Metab Disord. 1994;18(3):137-44.

26. Kim N, Son W, Lee B. Effects of Pilates mat exercise and detraining on metabolic hormone and coronary artery disease risk factor in obese middle aged women. Exerc Sci. 2009;18(1):65-74.

27. Choi, Hwa B, Kim, Hwan C. Effect of Pilates Mat Exercise on Low Back Pain, Lumbar Muscular Strength of Elderly, Pain Scale and Body Composition. Journal of Korea Sport Research. 2006;17(5):633-41.

28. Sharma R, Gupta N, Bijlani RL. Effect of yoga based lifestyle intervention on subjective well-being. Indian J Physiol Pharmacol. 2008;52(2):123-31.

29. Daley A, MacArthur C, McManus R, Stokes-Lampard H, Wilson S, Roalfe A, et al. Factors associated with the use of complementary medicine and non-pharmacological interventions in symptomatic menopausal women. Climacteric. 2006;9(5):336-46. 